\title{
PELASTUSRENGAS KOULUMAISESTA ELÄMÄSTÄ SELVIYTYMISEEN
}

\author{
Koskela, I. - Kallio, I. - Merenheimo, K. \\ 1990. \\ EI KOULUA VAAN ELÄMÄÄ VARTEN. Raportti \\ opetuksen laadun kehittämishankkeesta. Virkaili- \\ jain kansalaisopiston julkaisuja 2. 264 sivua.
}

$\mathrm{O}$ n ilahduttavaa, että kehittävän työntutkimuksen perinteellä on ryhdytty tarkastelemaan myös koulumaailmaa. Aikaisemminhan samaa on sovellettu $\mathrm{mm}$. siivoojien, tarjoilijoiden, sosiaalityöntekijöiden ja lääkärien työhön. Ei koulua vaan elämää varten -julkaisussa kerrotaan Virkailijain kansalaisopistossa toteutetusta opetuksen laadun kehittämishankkeesta. Lähtökohtana on työn tutkimus erityisesti kehittävän työntutkimuksen teoriaa soveltaen. Työtoiminnan analyysi koostuu kohdehistoriallisesta, teoriahistoriallisesta ja aktuaaliempiirisestä analyysista. Tätä analyysia typistettiin siten, että teoriahistoriallinen analyysi jäi pois, samoin aktuaaliempiirisestä jäi jäljelle vain ajattelumallien analyysi. Julkaisussa tosin todetaan, että ajattelu ja toiminta voivat olla keskenään ristiriidassa. Siten ajattelun muuttaminen ei välttämättä muuta toimintaa, ellei ristiriitoja pystytä ekspansiivisesti ratkaisemaan.

Kohdehistoriallisessa analyysissa on kuvattu opiston historiallisia vaiheita sekä analysoitu niitä ristiriitoja, joita kussakin vaiheessa esiintyi. Teksti on mielenkiintoisella tavalla sekoitus perinteistä kouluhistoriikkia ja kehittävän työntutkimuksen ristiriita-analyysia. Aineisto kerättiin kirjallisista dokumenteista sekä haastattelemalla kahta entistä rehtoria sekä useita opettajia. Viisi historiallista vaihetta opiston perustamisesta lähtien on esitetty kolmiomalleina ja eritelty osien välisiä ristiriitoja. Joitakin ristiriitoja on nosteitu erityisesti alleviivaten esille. Miksi näin on tehty, jää lukijan arvailun varaan: jos on kyse esimerkiksi tiedostetun ristiriidan ja tutkijan havaitseman ristiriidan havainnollistamisesta, millä perusteella erottelu on tehty ja miksi sitä ei sanota suoraan? Tällaisten asioiden arvaileminen ja raportin turha selaaminen ei ainakaan helpota lukemista.

Opetustarjonnan analyysit tehtiin kehittämisryhmissä, jolloin opettajat itse tutkivat oman työnsä historiaa. Tuotokset esimerkiksi vieraiden kielten ja taideaineiden osalta olivat selvästi eri- laiset. Vieraiden kielten osalta noudatettiin perusteellista "'kolmiomallia", mutta taideaineitten kuvaus oli lähempänä perinteistä tapahtumahistoriaa ilman ristiriita-analyyseja.

Opettajien ajattelu- ja toimintamallien tutkimukseen otettiin 36 opettajasta mukaan 11, joille esitettiin 22 kysymystä. Kun teemahaastattelut kestivät 25-45 minuuttia, ei kovin syvällisiin analyyseihin toiminnasta, ajattelun perusteista sekä tavoitteen ja todellisuuden ristiriidoista ollut mahdollista päästä. Tämä tulee ilmi myös haastattelulainauksissa, jotka esiteltiin taulukoin ja esimerkein sekä lyhyin kommentein ja ihmettelyin. Tulosten raportointi vaikutti pinnalliselta ja siinä näkyy teoriahistoriallisen analyysin puuttuminen. Tässä luvussa oli opettajien vastaukset purettu 27 ulkoasultaan samankaltaiseen taulukkoon, mikä ei enää edes kuulosta järkevältä. Jonkinlaisten jatkumojen luominen 11 opettajan vastauksista oli haparoivaa ja osittain aineiston analyysi oli suoraan haastattelujen referoimista asioiden mukaan allekkain.

$\mathrm{U}$ usien välineiden ja oppimistoiminnan muodostaminen jäivät yhteistyön lisäämiseen ja toisten opettajien tuntien seuraamiseen. Kun opettajat eivät haastattelujen perusteella kun on epätodennäköistä, että tuntien seuraaminen johtaisi työtoiminnan ristiriitojen tasokkaaseen analyysiin, tuloksena saattaa hyvinkin olla, että käsityömäinen työ konservoidaan.

Yhtenä kehittämisen välineenä käytettiin myös palautetta opiskelijoilta. Kuten muissakin kyselyissä tulokseksi saatiin, että opiskelijat ovat yleisesti ottaen tyytyväisiä siihen mihin ovat tottuneet. Lisäksi tehtiin suoranaisia markkinatutkimuksia potentiaalisten opiskelijoiden toiveista ja kartoitettiin mielikuvaa Virkailijain kansalaisopistosta. Kyselyn yhteenvedossa tekijät toteavat, että potentiaalisia opiskelijoita on paljon kaivanneet kovin korkeatasoista yhteistyötä ja 
kun vain heidät tavoitetaan ja tarjotaan juuri heidän tarvitsemaansa koulutusta. Siinäpä se.

Tarkennettu lähikehityksen vyöhyke on esitetty ennen kehittämisryhmien työskentelyn ja opetuskokeilujen raportointia. Se on kaunis, mutta tuskin lähikehityksen vyöhyke vielä pitkään aikaan. Kun työn tekijäksi on esitetty kehittämisryhmiä ja kun opettajien yhteistyötaidot kuitenkin ovat olemattomat ja saavutetut tulokset pikemminkin behavioristisen didaktiikan kielellisiä käännöksiä kognitiiviseen suuntaan, tarvitaan vahva usko, että kuvittelisi lähikehityksen vyöhykkeen sinne, mihin se on esitetty. Todellista lähikehityksen vyöhykettä ei voida johtaa pelkästään opiston tehtäväkäsityksen muutoksesta, vaan se muotoutuu vasta muutosyrityksissä ja kokeilutoiminnassa.

$\mathbf{P}$ ositiivista teoksessa on yritys. Tulos ei ole kuitenkaan vakuuttava. Kaiken aikaa paistaa läpi se, että jotkut osat Engeströmin koulutuksesta vastaavat niin hyvin omaa ajattelua, että ne on mahdollista toteuttaa myös käytännössä. Paikoitellen ollaan oltu muualla kuin lähikehityksen vyöhykkeellä, jolloin myös tulos on lähinnä mekaaninen sovellus. Vaarana kehittämisen kannalta on, että ristiriidat ratkaistaan tavalla, joka tuottaa rationalisoidun tai käsityömäisen työtyypin vahvistamisen sen sijaan, että opettajat pääsisivät teoreettisesti hallittuun työhön. Opitaan retoriikka mahdollisimman mekaanisesti, reflektoidaan ja ajatellaan ekspansiivisesti, mutta toimitaan sokeasti.

Raportti ei ole opinnäyte ja siksi tulee pohti- neeksi, kenelle ja miksi se on kirjoitettu. Jos tarkoitus on tiedottaa kehittämistyöstä tai markkinoida opistoa, pieni tiivistelmä ja jopa tekstin lyhentäminen olisi paikallaan. Pilakuvien ja irrallisten "aforismien" sijasta olisi kannattanut satsata edes puuduttavien frekvenssi- ja prosenttitaulukkojen havainnollistamiseen vaikkapa yksinkertaisilla kuvioilla. Tällaisena raportti on liian raskas toimimaan esimerkkinä muille, vaikka periaatteessa antaakin ko. opistosta kehittämismyönteisen kuvan. Epäilemättä kirjoittaminen on auttanut tekijöitä selvittämään omaa ajatteluaan ja samalla on saatu kaikki kokeiluun liittyvät kyselyt ja selvitykset yksiin kansiin. Kaiken kaikkiaan raportti on kokoelma seminaaritöitä, kyselyjä ja erilaisia projektitöitä, joita on sidottu yhteenvedoilla ja sijoittamalla niitä kehittävän työntutkimuksen vaihemalliin. Tulos on loogisesta etenemisestään huolimatta raskas ja sekavanoloinen. Ehkäpä se on opetuksen kehittämisen koko kuva.

Kokeilun aloitusvaiheesta ei ole paljonkaan kerrottu, vaikka opettajien motivointi opetuksen laadun kehittämiseen oli ja on hyvin vaikea haaste. Kehittäminen aloitettiin rehtorin ja kolmen opettajan voimin ja muita opettajia saatiin vaihtelevalla työpanoksella mukaan. Alusta lähtien kokeilu on ollut opiston itsenäinen hanke, vaikka samalla on oltu mukana parissa laajemmassa kehittämiskokeilussa. Näin on saatu moniin isoihin hankkeisiin liittyvä turha hallinnoiminen minimiin. Muutenkin kokeilussa on viitteitä siihen suuntaan, että puheesta ollaan siirtymässä todelliseen opetuksen kehittämiseen, ja sen toivoisi jatkuvan vielä raportin ilmestyttyäkin.

\section{PASI SAVONMÄKI JA HELENA RANTANEN}

